Hvorfor benægter verden, at den sande kærlighed skal findes i fuldkommenhedens bånd?

Nyborg, Ole

Published in:

Tidsskrift for Teologi og Kirke

Publication date:

2011

Document version

Også kaldet Forlagets PDF

Citation for published version (APA):

Nyborg, O. (2011). Hvorfor benægter verden, at den sande kærlighed skal findes i fuldkommenhedens bånd? Tidsskrift for Teologi og Kirke, 2, 280-297. 


\section{HVORFOR BENAGTER VERDEN, AT DEN SANDE KARLIGHED SKAL FINDES I FULDKOMMENHEDENS BÅND?}

\section{OLE NYBORG}

Teologisk Fakultet, Københavns Universitet

Langelandsvej $391 \mathrm{TV}$

2000 Frederiksberg, Danmark

onb@teol.ku.dk

$\begin{array}{lllllllllllllll}\text { A } & B & S & T & R & A & C & T\end{array}$

In this paper the conception of Christian love within the texts of the Danish theologian N. F. S. Grundtvig (1783-1872) is analyzed. In these texts we find an implementation of the Biblical quotation from Colossians 3, 14: «And above all these things put on charity, which is the bond of perfectness» (King James Bible). Grundtvig strongly criticises contemporary popular ideas of the concept of love. The Biblical expression of the bond of perfectness does not describe a sort of love coming from natural man. This bond of perfectness is the work of the heavenly father and this bond is according to Grundtvig also a matter of constraint, discipline, and obligation. Those true Christians who have left the world and entered the Christian congregation and entered the fatherly community of the bond of perfectness are subdued to a sort of voluntary force and they accept to follow in the footsteps of Jesus all the way to the cross and crucifixion. To be a true Christian within the boundaries of the bond of perfectness is to accept self-humiliation and selfdegradation. In this way according to N. F. S. Grundtvig the concept of love popular in the world is quite wrong and illusionary.

KEY WORDS

- $19^{\text {th }}$ Century theology

- the concept of Christian love

- interpretation of Colossians 3, 14: bond of perfectness 
- N. F. S. Grundtvig,

- Romanticist and Modern conceptions of love

- conception of the Christian congregation

- the idea of the importance of fatherliness

Men over alt dette skal I iføre jer kærligheden, som er fuldkommenhedens bånd. Kristi fred skal råde i jeres hjerter; til den blev I jo kaldet som lemmer på ét legeme. Og vær taknemlige (Kolossenserbrevet 3, 14-15).

\section{INNLEDNING}

Den danske teolog og prædikant N. F. S. Grundtvig (1783-1872) anvendte i sine salmer, prædikener og øvrige forfatterskab i en del tilfælde det bibelske udtryk om «Fuldkommenheds Baand». Det er tydeligt, at en af de vigtigste pointer, som Grundtvig havde i forbindelse med, at han anvendte udtrykket «Fuldkommenheds Baand», var at sige, at teologerne og filosofferne ude i verden talte ivrigt og ofte om kærligheden, men at de ikke havde nogen sand forståelse af denne kærlighed. I en af sine prædikener siger Grundtvig således:

Derfor er der endnu en Ting for os at giøre, den nemlig at vogte os for alle de falske, tomme og unaturlige Indbildninger om Kiærlighed, som vi enten selv har optænkt eller fundet hos de Verdsligvise. ${ }^{1}$

I de følgende afsnit skal gives en oversigt over den hidtidige forskning vedrørende Grundtvigs opfattelse af udtrykket «Fuldkommenheds Baand», og derefter skal Grundtvigs brug af udtrykket analyseres. En række eksempler vil blive givet på Grundtvigs faktiske brug af udtrykket. Disse eksempler vil blive taget fra hans prædikener, salmer og øvrige forfatterskab. Til sidst skal gives en samlet analyse af Grundtvigs brug af udtrykket «Fuldkommenheds Baand».

\section{GRUNDTVIG-FORSKNINGEN OM GRUNDTVIGS BRUG AF UDTRYKKET «FULDKOMMENHEDENS BAAND»}

I forbindelse med nærværende undersøgelse er den danske og ikke-danske Grundtvig-forskning siden 1945 blevet undersøgt for at finde analyser af Grundtvigs begreb om «Fuldkommenheds Baand».

Det overordnede billede er, at denne Grundtvig-forskning ofte i en slags sidebemærkninger har omtalt Grundtvigs brug af «Fuldkommen- 
heds Baand», men at der kun findes ganske få eksempler i denne forskning på en egentlig analyse eller forklaring af Grundtvigs brug af udtrykket «Fuldkommenheds Baand». I betragtning af den vægt og vigtighed, som Grundtvig tillægger dette udtryk, må dette fravær af en analyse eller forklaring af Grundtvigs sprogbrug siges at være meget overraskende.

Hvis denne forskningslitteratur gennemgås, viser der sig et andet alment træk: I denne litteratur er Grundtvigs udtryk om «Fuldkommenheds Baand» i næsten alle tilfælde ganske enkelt blevet oversat til ordet «kærlighed» og til den abstrakte tanke om, at mennesker skal leve i kærlighed. ${ }^{2}$

Som et nyligt eksempel fra denne forskning kan nævnes den danske Grundtvig-forsker Uffe Jonas. Jonas gennemfører en vidtgående omtolkning af Grundtvigs tankegang. Jonas fortolker - lige som Kaj Thaning i 1963 - Grundtvig ind i en slags sekulariseringstankegang og skabelsesteologi. Jonas tilslutter sig den thaning'ske tese om, at Grundtvig tænkte efter reglen «Menneske først og kristen så», og han fortolker Grundtvig på en måde, så det særligt kristelige bliver underordnet i den grundtvigske tankeverden.

Den åndelige vækst hos Grundtvig inden for «Fuldkommenheds Baand» tolker Jonas som en personlig, psykologisk, spirituel eller psykoterapeutisk udvikling og fremgang især på den måde, at sjæl, ånd og krop integreres i individet, og mennesker lærer at acceptere og elske deres krop og seksualitet. Den kærlighed og det fuldkommenhedens bånd, som Grundtvig taler om, fortolker Jonas som menneskets naturlige individuelle tilbøjeligheder og følelser. Jonas tillægger på den måde også Grundtvig en optimistisk opfattelse af det naturlige ikke-kristne menneske:

Den daglige overbinding fra det, som Grundtvig kalder for det gammelmenneskelige til det nymenneskelige, foregår ikke kun i kirken og menigheden, men nok så meget i hjemmet, blandt kærlige ægtefolk. For det er ikke nødvendigvis de bogstaveligt rettroende, men snarere de elskende, der er de sande indbyggere og medbyggere i det ny Jerusalem. Det er her, i de usynlige sprækker mellem nadvergangen, salmesangen og ægtesengen, at man skal finde sporene af den skjulte menighed. ${ }^{3}$

\section{GRUNDTVIGS PRÆDIKEN «PINDSE-DAG 1839»}

I en prædiken «Pindse-Dag 1839» taler Grundtvig indgående om, hvorledes det bibelske udtryk «Fuldkommenheds Baand» skal forstås. I forhold til samtiden og det danske folk optræder Grundtvig ofte i sine prædikener som en revsende domsprædikant, og i denne prædiken omtaler han da 
også tidens manglende kærlighed og ikke mindst manglende forståelse af den sande betydning af ordet kærlighed. Den sande kristelige kærlighed består ikke i ømme følelser, ${ }^{4}$ men i at opgive verden, fornægte sig selv, følge Jesus og opofre sit liv for Herren.

Grundtvig taler således om:

den Mangel paa himmelsk Glæde og brændende Kiærlighed, derfor ogsaa paa Sind til at opgive Verden og opoffre sig for Herren. ${ }^{5}$

I sin pinse-prædiken beskriver Grundtvig den første kristne menighed i Jerusalem, som i høj grad i Grundtvigs tekster er et billede på «Fuldkommenheds Baand». Det, som vi ifølge Grundtvig kan se hos denne menighed, er, at de kristne ikke længere er enkelte individer, men sammensmeltede og sammensnørede til en sjæl og et legeme, og deri består ifølge Grundtvig netop det væsentlige $\mathrm{i}$ «Fuldkommenheds Baand». Medlemmerne af denne første kristne menighed tænker ikke længere deres egne tanker, og de har ikke længere deres egne følelser, og beviset ifølge Grundtvig for denne tilstand er, at de går i Jesu fodspor, glæder sig, når de forfølges, og lige som den hellige Stefan er villige til at lide martyrdøden «med Tak til Herren og Bøn for deres Bødler».

«Fuldkommenheds Baand» består ikke ifølge Grundtvigs prædiken i, at mennesker enkeltvis eller i flok elsker eller i kærlighed forbinder sig med Gud. «Fuldkommenheds Baand» består i det samfund, som er blevet bundet sammen ovenfra og ned. Alene eller enkeltvis kan jordens mennesker ifølge Grundtvigs prædiken ikke komme ud af deres selvrådige, indelukkede individualitet og smelte sammen i en højere ild til en sjæl og et legeme. Det kan kun Gud gøre.

På den måde skaber den himmelske fader et nyt rige på jorden:

Himmeriget paa Jorden i Jerusalem, hvor Kiærlighed, som Fuldkommenheds Baand, sammenknyttede de Troende i Tusindtal, saa de var eet Hjerte og een Sjæl, og det guddommelige Heltesind i Apostlerne og deres første Disipler, der var glade naar de vanæredes for Jesu Navns Skyld, og leed Martyrdøden med Tak til Herren og Bøn for deres Bødler. ${ }^{6}$

\section{MARTYRIET OG «FULDKOMMENHEDENS BAAND»}

I sin prædiken på den 2. juledag 1838 fremhæver Grundtvig en lignende tanke. Ifølge verden er martyriet en gru og rædsel, men for de sande 
kristne er martyriet udtryk for den højeste godhed, dyd og kærlighed. At være en sand kristen er at gå «i Jesu Christi Fodspor», og Stefan var netop den første, som gik i Jesu fodspor, og som gik hele vejen. Stefan består den endegyldige prøve og prøvelse, og han beviser dermed, at han er blevet og fundet værdig til at indgå i Himmeriget. Den «hellige Stephan» er et «Mønster», et ideal og en målestok for alle sande kristne. Når de ser på Stefan, bliver de glade og trøstede. De kan se, at det er blevet realt muligt for dem at nå det fuldkomne. Når de ser på, hvordan den hellige Stefan som en slags ældre broder bestod den store prøvelse, får de et fornyet håb.

Fuldkommenhedens bånd betyder i Grundtvigs prædiken fra 1838 tydeligt nok ikke bare «kærlighed». «Fuldkommenheds Baand» er den nødvendige ydre ramme og kontekst om den kristelige vækst. En sådan forandring er kun realt mulig inden for rammerne af «Fuldkommenheds Baand», og kun inden for grænserne af dette «Fuldkommenheds Baand» kan der forekomme sådanne mennesker, som Grundtvig i sine prædikener kalder «Venner». I Grundtvigs prædikener er disse «Venner» mennesker, der lige som Grundtvig selv har forladt denne verden, og som er i gang med at modtage en ny karakter, og hvis gamle natur gradvist tilintetgøres, opbrændes og omsmeltes i «Fuldkommenheds Baand».

Inden for rammerne af dette «Fuldkommenheds Baand» foregår der ifølge Grundtvigs prædiken en skoling, dannelse og karakterforandring. Fortællingen om den hellige Stefan er ifølge Grundtvigs prædiken den centrale kristne fortælling og er nøglen til at forstå meningen med det bibelske udtryk om, at de kristne skal iføre sig «Fuldkommenheds Baand». At iføre sig «Fuldkommenheds Baand» er at være villig til at ofre sig, fornægte sig selv og give sit liv for sine venner. Den hidtidige danske og ikke-danske Grundtvig-forskning om Grundtvigs brug af udtrykket «Fuldkommenheds Baand» har overset denne centrale fortolkning hos Grundtvig af fuldkommenhedens bånd som en binding, et bånd, en opdragelse og karakterforandring, som er forbundet med en lidelse, et afkald og et offer, og som kun er realt mulig i et slags faderligt tugtende samfund.

I sin prædiken på den 2. juledag 1838 siger Grundtvig om «Fuldkommenheds Baand»:

Christne Venner! Barne-Tro, Ungdoms-Ild, Manddoms-Kraft og Oldings-Viisdom, det er Elementerne i det Christelige Helteliv, som efterhaanden skal sammensmelte i den himmelske Kiærlighed, som er Fuldkommenheds Baand, og som et Mønster paa en saadan 
christelig Helt har den hellige Stephan ligefra Apostlernes Dage svævet for Menigheden og kan vi ikke følge ham endnu, saa skal vi dog følge ham herefter, ligesom han fulgde Herren. Ja, mine Venner! det er det glædelige Lys (...) hvori vi skal lære at betragte alt Christeligt, den Oplysning, at hvad som er tilforn skrevet om de Hellige og Udvalgte [Stephan], det er hverken skrevet til ørkesløs Beundring eller til at binde svare Byrder af, som tynge os til Jorden, men til et lysende Exempel, til en venlig Trøst og velgrundet Haab, saa vi opmuntres derved til at giøre vort Bedste og lettes efterhaanden til at løfte os over Jorden og vandre med Gud. ${ }^{7}$

\section{GRUNDTIVGS BRUG AF «FULDKOMMENHEDENS BAAND» I SALMEN «LET ER MIN BYRDE»}

Grundtvigs salme «Let er min Byrde» fra 1855-1856 indeholder en gengivelse i kort form af en række forestillinger, som i Grundtvigs tekster lige som i et netværk - knyttes til den semantiske enhed «Fuldkommenheds Baand». ${ }^{8}$

Udtrykket «Hans Aag er lifligt og Hans Byrde er let» er et af de mest almindelige udtryk i Grundtvigs prædikener. Ikke sjældent fortolker Grundtvig Herrens åg og byrde som det kristne martyrium altså den nødvendige skæbne og det nødvendige endemål, hvor det kristne menneske til sidst bliver et med Kristus i selvfornægtelsen, selvfornedrelsen, korsfæstelsen og martyrdøden. ${ }^{9}$

Som et eksempel på, at Grundtvig sammenkæder (a) tanken om «Fuldkommenheds Baand» og (b) udtrykket om Herrens åg og byrde med (c) tanken om det kristne menneskes korsfæstelse og martyrdød kan anføres det følgende citat fra Grundtvigs prædiken på palmesøndag 1839:

Ja, i Kraft skal de træde, alle de gode Ord, som vor Gud har talt over os og vore Fædre, ikke Et af dem skal falde til Jorden (...) Er det ny Menneske kun svagt og spædt i os eller dog i sin første Opvext, saa er der dog samme Sind, som i Jesus Christus (...) fordi Ingen gaaer paa den, Livets Vei [Jesu vej til korset], kiendelig fra alle Andre [Veie] paa vor Herres Jesu Christi uudslettelige og lysende Fodspor, saa ogsaa nu er de Christne stærke i Herren og kan i Hans Kraft fare i Guds fulde Harnisk, ogsaa nu kan de fornægte sig selv, tage Korset op og følge ham, ikke tvungen men frivillig, ikke klynkende men sjungende: (...) Hosianna i høien Sky! Jesus Christus er vor Herre (...) Han lægger os en Byrde paa, men Han 
er vor Sandheds Gud, som udfrier fra Døden [martyrdøden], Hans Aag er lifligt og Hans Byrde er let! ${ }^{10}$

Som det fremgår af nogle af de nedenfor citerede udtryk fra Grundtvigs salme «Let er min Byrde», synes Grundtvig med «Herrens Aag» at tænke på det kristne martyrium altså på det offer, selvoffer, den selvfornedrelse og selvfornægtelse, som det kristne menneske skal gennemleve for at nå målet og frelsen.

Kun ad det Aag kan vi smile,

Som giver Sjælene Hvile!

\section{( ...)}

Hvad er din Byrde,

Og hvad er dit Aag?

Byrden: Guds Kiærligheds Tro,

Den giver Sjælene Ro.

Når det kristne menneske siger farvel til verden og kommer ind i den kristne menighed, som er Jesu Kristi legeme, bliver det menneske tvunget og underkastet en ifølge Grundtvig nødvendig faderlig tvang. Det er denne tvang og nødvendighed, som Jesus taler om, når han siger: Mit åg er lifligt! Det kristne menneske mister sin frihed i verdens forstand, og det kristne menneske bliver fanget, indfanget og tvunget. Det er ifølge Grundtvig essensen af det «Fuldkommenheds Baand», som det kristne menneske indgår i, underkaster sig eller ifører sig, når det omvender sig eller vender sig bort fra denne verden.

Ifølge Grundtvigs tankegang har ethvert menneske altid en herre over sig. Enten har det menneske den onde djævel til sin fader, herre og mester, eller det kan valge at have Kristus som sin fader, herre og mester. Den vilkårlige frihed eller «liberum arbitrium» altså friheden til at gøre, hvad man har lyst til, er ifølge Grundtvig ikke mulig, og den er heller ikke $\emptyset n$ skelig. Den sande frihed er ikke en frihed til at følge sine egne tanker eller følelser. Den sande frihed består i at gøre det gode nemlig at tænke sin faders, herres og mesters tanker, have hans følelser og gøre hans gerninger. Livet i menigheden og inden for rammerne af «Fuldkommenheds Baand» må derfor nødvendigvis indebære en form for opdragelse og tvang. Frivilligt eller ud fra deres egne naturlige tanker og følelser ville jordens mennesker ifølge Grundtvig aldrig begynde at gøre det gode: 
Aaget er Tvangen,

Hjertet er Fangen,

Liflig Guds Kiærligheds Finger

Hjerterne fanger og tvinger!

\section{$(\ldots)$}

Byrden, med Fred og med Haab,

Det er din Pagt ved vor Daab.

Ved nadveren lyder det til det kristne menneske: Du skal drikke denne kalk! Det åg, som Jesus taler om, og som Jesus beskriver som lifligt, består $i$, at det kristne menneske skal drikke denne kalk og dette bæger. Den kalk, som det kristne menneske skal drikke ved nadverbordet, er en byrde og et åg, som Kristus lægger ned over det kristne menneske, og denne kalk er ifølge Grundtvig den samme kalk, som Jesus var nødt til at drikke umiddelbart forud for sin korsfæstelse. At drikke dette bæger er derfor et slags «Aag». Når nadvergæsten drikker denne kalk udfører han $i$ en vis forstand den samme handling, som Jesus udførte umiddelbart forud for sin martyrdød. At drikke kalken ved nadverbordet er en handling, hvor det kristne menneske accepterer selvfornægtelsen, martyriet og korsfæstelsen som sin snarlige uundgåelige skæbne.

Aaget er Ordet

Til os ved Bordet

Det er Fuldkommenheds-Baandet

Som du dit Liv har indaandet!

\section{GRUNDTVIGS BESKRIVELSE AF «FULDKOMMENHEDENS} BAAND»I EN PRÆDIKEN FRA 1833

I en prædiken «2den Faste-Søndag 1833» giver Grundtvig en beskrivelse og forklaring af «Fuldkommenheds Baand» ud fra evangelieteksten om Jesu helbredelse af den kanaanæiske kvindes datter (Mattæusevangeliet 15, 21-28). ${ }^{11}$ Grundtvig siger i denne prædiken, at den sande forståelse af «Fuldkommenheds Baand» er en slags mellemvej mellem opfattelsen i den romersk-katolske - ifølge ham - tvangskirke og den modsatte moderne opfattelse af kirken og menigheden, hvor kirken bliver helt opløst i blotte individer uden nogen som helst bånd eller lænker.

Den romerske opfattelse indebærer ifølge Grundtvig, at mennesker binder hinanden med tvang. Den romerske opfattelse har ifølge Grundt- 
vig forstået en del af sandheden derved, at den forstår, at det er helt nødvendigt, at et kristent menneske bliver bundet med en slags bånd og lænker efter sin indgang i menigheden, men den romerske kirke mener helt fejlagtigt, at det er mennesker, som indbyrdes skal binde hinanden, og at det kan ske ved en ydre tvang.

Den individualistiske, moderne, liberalistiske opfattelse af kirken har slet ikke forstået, at de kristne i menigheden skal bindes til at være et legeme og en sjæl. På den måde har hverken den romerske eller liberale opfattelse ifølge Grundtvig forstået meningen med det sande «Fuldkommenheds Baand».

Den sande opfattelse af «Fuldkommenheds Baand» indebærer ifølge Grundtvig, at de kristne bliver bundet ovenfra og ned af deres fader og konge. De kristne går frivilligt ind under dette bånd. De tvinges ikke ved nogen ydre jordisk magt som i den romerske kirke, men «Fuldkommenheds Baand» betyder, at et bånd bliver lagt ned over de kristne således, at de på en vis måde sammenlænkes og sammensmeltes $\mathrm{i}$ en slags frivillige bånd og kæder:

Ogsaa det [en romersk katolsk opfattelse af kirken], har Erfaring lært os, er en farlig Sag for hvem der vil blive ved Christum, thi da [i den katolske «tvangs» kirke] opløses efterhaanden det Fuldkommenhedens Baand som i Kiærlighed skal omslynge os alle (...) naar vi skal alle være Eet i Christo Jesu, saa enten sammenlænke vi os [selv] da med Tvangs-Baand som er Slave-Kiæder, eller vi gaae hver sine Veie og maae i begge Tilfælde smertelig erfare at Herren bliver borte for os, og Troen paa ham (...) bliver os til Byrde. ${ }^{12}$

Grundtvig fortsætter i den samme prædiken med at forklare naturen af «Fuldkommenheds Baand» altså naturen af det samfund, som opstår mellem de kristne i menigheden og deres herre, fader og konge Kristus. At fuldkommenhedens bånd på den måde netop hos Grundtvig er et samfund eller socialt system er blevet overset og forbigået i Grundtvig-forskningen. Men kvinden, som optræder i evangelieteksten, viser os ifølge Grundtvig, hvad det vil sige at være et medlem af eller en deltager i «Fuldkommenheds Baand» forstået som et samfund, og beretningen om den kanaanæiske kvinde viser os ifølge Grundtvig, på hvilken måde det kristne menneske optugtes og opdrages inden for rammerne af «Fuldkommenheds Baand». Evangeliet giver os et billede af, på hvilken måde den faderlige opdragelse finder sted i menigheden og inden for rammerne af kærligheden og «Fuldkommenheds Baand»: 
Den lyksalige Kvinde (...) giver sig lydelig og tydelig tilkiende som hun der raaber efter ham: Herre, du Davids Søn! forbarm dig over mig, som, naar han tier og ligesom giør sig døv, trænger ind paa ham, kaster sig i Støvet for ham og gientager trøstig sit: Herre! hjelp du mig! og som endelig naar han lader som han vil spise hende af med Steen for Brød, afvise hende haanlig, lader sig deraf hverken forbittre eller forvirre, men tager det for en Prøvelse, som det er, tilegner sig Skammen som velforskyldt, men suger Honning af Giften, og giør det derved umueligt for Herren at skjule sig længer, lader sig gierne kalde en Hund, hvor det ikke giælder om et Been men om det Brød, hvis mindste Krumme mætter til et evigt Liv! ${ }^{13}$

Inden for grænserne af «Fuldkommenheds Baand» optræder Kristus som en herre, fader og opdrager. De mennesker, som er givet i hans varetægt, har ifølge Grundtvigs prædiken i udgangspunktet ingen naturlig værdi i sig selv og ingen godhed, retfærdighed eller dyd. De, som skal have nogen glæde af opdragelsen i samfundet og $\mathrm{i}$ «Fuldkommenheds Baand», skal give afkald på alt det jordiske og kødelige, som de naturligt elsker. De skal give afkald på selvet og individualiteten, stoltheden, selvrådigheden, selvklogskaben og personligheden og fornægte sig selv. Hvis vi, som er kristne, skal afdø fra vores individualitet og sammensmelte til et legeme og en sjæl, skal vi ifølge Grundtvig lige som Abraham «glemme vor Moder og vor Faders Huus», hjem, folk, venner, fædreland og ejendom.

De mennesker, som er givet til Kristus i hans egenskab af at være en opdrager, fortjener egentlig ikke hans kærlighed, og de er ikke elskværdige, men gennem den faderlige ansvarlige tugtende opdragelsesproces bliver disse små og svage, som oprindeligt levede i mørket, efterhånden værdige til at modtage kærligheden. Denne gradvise forvandlingsproces er den centrale proces $\mathrm{i}$ «Samfundet» og $\mathrm{i}$ «Fuldkommenheds Baand» og er ifølge Grundtvigs prædiken den egentlige mening med udtrykket om, at «Fuldkommenheds Baand» er «Kiærligheden»:

Vel er den Kvinde i os (...) hedensk af Byrd (...) saa hun maa være belavet paa at finde hos Herren hvad der ligner døve Øren og hvad der klinger haardt, men naar Samfundet (...) med Herren lever op hos os, saa vi glemme vor Moder og vor Faders Huus, da veed vi, Kongen finder Behag i os (...) da smelter Hjertet $\mathrm{i}$ ham, da giver Han med begge Hænder. ${ }^{14}$ 


\section{CHRISTENHEDENS SYVSTJERNE OG «TYSKER-MENIGHEDEN"}

Christenhedens Syvstjerne er en slags versificeret kirkens historie, som Grundtvig skrev i årene 1853 og 1854. Også i dette epos behandler Grundtvig spørgsmålet om den rette forståelse af det bibelske udtryk om «Fuldkommenheds Baand». I afsnittet om «Tysker-Menigheden», som først og fremmest beskriver Martin Luthers betydning for den kristne kirke, skriver Grundtvig således i strofe 104:

\footnotetext{
Snart nu sees ved Naade-Bordet,

Hvad selv Engle studse ved,

Sees i Troens Favn Guds-Ordet:

Herren med sin Menighed,

Som ei nogen Trold forstener,

Som Gud-Fader selv forener

Med Fuldkommenhedens Baand! $!^{15}$
}

Grundtvig forudser her i midten af 1850-erne, at en ny vækkelse og form for kristenliv vil bryde igennem i Danmark, som er præget af «Fuldkommenheds Baand». I nadveren begynder det kristne menneske at sammensmelte med Kristus, og dermed er det netop i nadveren, at det kristne menneske påtager sig at følge Kristus, og om fornødent at dø en martyrdød. Det, som mennesker og engle næsten ikke kan forstå, og som verden ikke vil acceptere som muligt, er, at Gud har gjort det muligt for mennesker, der vender sig bort fra verden, at smelte sammen med Kristus og smelte sammen med hinanden, så deres individualitet, personlige særpræg, selviskhed og selvrådighed trænges tilbage.

«Fuldkommenheds Baand» er ikke ifølge Christenhedens Syvstjerne et bånd, som stammer fra mennesker. «Fuldkommenheds Baand» er det bånd, som den himmelske fader snører rundt om Kristus og de sande kristne, som lever i faderens hus eller i den kristne menighed. Når man bliver en kristen, bliver man bundet af dette bånd, og derved mister man den såkaldte frihed, som verden taler så ivrigt om, men som ifølge Grundtvig kun eller mest er en frihed til at gøre det onde. ${ }^{16}$ Hvis mennesker kun agerer som individer i verden, kan de ikke blive en sjæl og et legeme. Verden, som befinder sig uden for den kristne menighed, stræber ifølge Grundtvig efter at tilintetg $\varnothing$ re dette «Fuldkommenheds Baand», som Gud har lagt ned over de kristne i menigheden. Verden forstår ikke betydningen af og accepterer heller ikke nødvendigheden af dette bånd på det naturlige menneske.

I den følgende strofe 105 fortsætter Grundtvig med at tale om «Fuldkommenheds Baand». Grundtvig understreger det element af tvang og 
ubehag, der dybest set ligger i «Fuldkommenheds Baand», men dette bånd er noget, som på en positiv måde tvinger, presser og styrer det kristne menneske. I «Fuldkommenheds Baand» er det kristne menneske så at sige kommet $\mathrm{i}$ et slags fængsel, og det har mistet det, som verden kalder «frihed». At leve inden for «Fuldkommenheds Baand» er på en vis måde og i al fald i verdens øjne at opleve en menneskelig smerte eller brand. Grundtvig henviser i denne strofe til, at «Fuldkommenheds Baand» indebærer, at det kristne menneske til sidst må være villigt til at dø martyrdøden og på den måde endegyldigt opgive sit eget ego og fornedre og fornægte sig selv:

Ja, det Baand, som os til Vinger

Voxer ud i Jesu Navn,

Som kun Frihed os paatvinger,

Fængsler kun i Naadens Favn,

Brænder kun, som Glæden flammer

I Guds-Husets Brude-Kammer,

Er Gud-Faders Kiærlighed $!^{17}$

\section{DET DANSKE FIIR-KLØVER FRA 1836 OG «GYLDEN-AARET» FRA 1834}

Det bibelske udtryk om «Fuldkommenheds Baand» og den dermed forbundne tankegang anvendte Grundtvig også i forbindelse med helt jordiske eller samfundsmæssige forhold. Et eksempel er hans skrift Det Danske Fiir-Klover fra 1836, hvor Grundtvig udviklede en slags almen samfundsfilosofi. I dette værk beskriver han relationen mellem det danske folk og dets landsfader med udtryk, som er helt analoge til den måde, som han i sine prædikener og salmer beskriver relationen mellem Kristus og menigheden:

Tal aldrig om Frihed, hvor Fyrsten er Trel,

Men sjunger, Smaa-Fugle, om Dannemarks Held,

Hvor Fredegods-Tiden sig klarlig fornyer,

Hvor Friheden hersker og Trældommen flyer,

Hvor Kongen og Folket, med Mund og med Haand,

Til Skyerne løfte »Fuldkommenheds Baand «! ${ }^{18}$

I sit digt «Gylden-Aaret» fra 1834, som er en beskrivelse af og profeti om det danske enevældige samfund, forklarer Grundtvig også «Fuldkom- 
menheds Baand» med udtryk, som helt svarer til hans beskrivelser af «Fuldkommenheds Baand» i den kristne menighed:

Et Lys sig da udbreder,

Som trindt i Mark og Skov

Om Liv og Sandhed freder,

Forklarer Friheds Lov,

Som Idræt, Ord og Tanker

Kun holder saa i Skranker

At Frihed kan bestaae! ${ }^{19}$

De ovenfor citerede strofer viser meget tydeligt, hvordan Grundtvig netop fortolker fuldkommenhedens bånd som et faderligt samfund eller socialt system og ikke blot som individets knytten sig i kærlighed til en anden part eller agent, således som Grundtvigs tanke om kærligheden som fuldkommenhedens bånd er blevet fortolket i Grundtvig-forskningen. ${ }^{20}$

\section{EN FORKLARING AF ORDENE «BÅND» OG «BINDE» I GRUNDTVIGS TEKSTER}

Når der i Grundtvigs tekster tales om «Fuldkommenheds Baand», rejses der direkte eller indirekte fire forskellige spørgsmål:

Det første spørgsmål kan formuleres således: Hvem eller hvilke agenter bliver bundet? Hvem er så at sige objektet for denne handling at binde? Svaret i Grundtvigs tekster er, at de mennesker, som har omvendt sig til Kristus, bliver i og med «Fuldkommenheds Baand» bundet til Kristus.

Det andet spørgsmål kan formuleres således: Hvem eller hvilke agenter er den aktive part, som binder, eller hvem er subjektet i handlingen? I Grundtvigs tekster er det den faderlige agent, som er den aktive part. Når Grundtvig taler om den kristne menighed, taler han oftest om, at den himmelske fader eller "Gud Fader» binder de omvendte kristne til Kristus, eller han kan i sjældnere tilfælde sige, at Kristus er den aktive part, som binder de kristne til sig selv.

«Fuldkommenheds Baand» etablerer ifølge Grundtvigs tekster et sandt samfund, og et sådant ægte samfund etableres ifølge Grundtvig ovenfra og ned ved en handling fra den faderlige agents side. Et ægte fællesskab eller samfund kan ikke ifølge Grundtvig etableres nedefra og op eller ved en gensidig aftale, en venlig kontrakt eller kærlig forening af individer.

Den kristne menighed består ikke ifølge Grundtvig af en mængde af individer, som har fundet sammen, fordi de har de samme religiøse fore- 
stillinger. Den kristne menighed består af dem, som den faderlige guddommelige agent har udvalgt og taget ud af verden. Et «Folk» er i Grundtvigs tekster altid et «Folk», fordi det er blevet udvalgt af en konge - uanset om det drejer sig om «Christen-Folket» eller om et af «VerdensFolkene».

Det tredje spørgsmål, som Grundtvigs tekster søger at besvare, er: Hvad indebærer selve det at blive bundet? Tanken i Grundtvigs tekster er, at det at blive bundet er en begivenhed, som foregår i et bestemt punkt. I det punkt siger det pågældende menneske farvel til sit gamle selv og til denne verden på den måde og muliggjort af det faktum, at det af en faderlig agent bliver befriet for og taget ud af verden. I dette punkt får det pågældende menneske en ny identitet og på den måde holder det op med at være sig selv. At passere periferien til «Fuldkommenheds Baand» er selvets og det individuelle særegne livs ophør og død. Tidligere var dette menneske bundet til verden, men efter sin omvendelse og efter at have passeret periferien til «Fuldkommenheds Baand» er det bundet til Kristus. Det lever nu inden for rammerne og afgrænsningen af «Fuldkommenheds Baand».

Den vilkårlige bevægelses- og handlefrihed eller den «frie vilje», som det pågældende menneske måske havde forud for denne omvendelse - en frihed til at følge sine egne værdier, ønsker eller lyster - mister det pågældende menneske, når det kommer ind $\mathrm{i}$ «Fuldkommenheds Baand». At komme ind i «Fuldkommenheds Baand» indebærer ifølge Grundtvigs tekster tydeligt nok, at mennesker mister en bestemt form for frihed - en vilkårlig individuel handlefrihed, sådan som Grundtvig kendte den fra de liberalistiske filosoffer.

Det fjerde spørgsmål, som Grundtvigs tekster søger at besvare, kan formuleres således: Hvad betyder det at vare bundet? Det menneske, som er kommet ind i «Fuldkommenheds Baand», tænker ikke længere ifølge Grundtvigs tekster sine egne tanker, det har ikke længere sine egne følelser, og det gør ikke længere sine egne gerninger, men sin faders gerninger. På den måde er der i Grundtvigs tekster et tydeligt skel - en «Paradisets Mur» eller «Sions Mur»-mellem denne verdens børn, som følger deres egne tanker og følelser, og lysets børn, som gør deres faders gerninger og lærer at have hans tanker og følelser. ${ }^{21}$

«Fuldkommenheds Baand» er på den måde et slags åndeligt og moralsk system, som er omgivet af en klar grænse i forhold til den omgivende verden. At befinde sig inden for rammerne af «Fuldkommenheds Baand» er at befinde sig i en opdragelsesproces, hvor det gamle syndige egoistiske naturlige menneske gradvist fortrænges. At leve som et medlem af 
og en deltager $\mathrm{i}$ «Fuldkommenheds Baand» indebærer, at mennesket underkaster sig en vis tvang, disciplin og tugt. ${ }^{22}$

Grundtvig-forskningen har ofte hævdet, at Grundtvig havde et optimistisk syn på det naturlige menneskes muligheder for at udvikle sig til et kærligt menneske, ${ }^{23}$ men denne fortolkning af Grundtvigs tekster svarer ikke til Grundtvigs egne formuleringer. Over for det naturlige menneske må en faderlig agent nødvendigvis ifølge Grundtvig anvende en vis tvang, og det er også det, som Grundtvig beskriver, når han taler om «Fuldkommenheds Baand».

At leve inden for «Fuldkommenheds Baand» indebærer, at det kristne menneske lærer, at det skal gå i Jesu fodspor og derfor nødvendigvis må fornægte og fornedre sig selv. Inden for rammerne af «Fuldkommenheds Baand» lærer mennesker efterhånden en ny godhed, dyd og kærlighed og lærer at efterligne Kristus, og de indser, at hvis de skal efterfølge Kristus, må de drikke den samme kalk, som Jesus drak umiddelbart forud for sin korsfæstelse. I Grundtvigs tekster er der på den måde en nøje sammenhæng mellem tanken om «Fuldkommenheds Baand» og det kristne menneskes villighed til at ofre sig og sætte sit liv til og tage sit kors op og følge Jesus.

\section{HYPPIGHEDEN AF GRUNDTVIGS BRUG AV UDTRYKKET «FULDKOMMENHEDENS BAAND»}

Materialet for denne artikel er Grundtvigs tekster og især hans prædikener mellem 1832 og 1856. Grundtvig anvender udtrykket «Fuldkommenheds Baand» langt hyppigere i sine prædikener i de to kalenderår $1847 \mathrm{og}$ 1848 end i de øvrige år i den undersøgte periode. I kalenderåret 1847 forekommer udtrykket «Fuldkommenheds Baand» i ikke færre end 10 og i kalenderåret 1848 i 11 prædikener. I årene fra 1832 til 1846 forekommer «Fuldkommenheds Baand» i gennemsnit hos Grundtvig i kun to prædikener om året.

Det er derfor naturligt at spørge om, hvorfor Grundtvig anvender udtrykket langt hyppigere i $1847 \mathrm{og}$ i 1848. Ligeledes er det naturligt at undersøge, om denne meget hyppigere brug af udtrykket «Fuldkommenheds Baand» netop i disse to politisk dramatiske år kan fortælle os noget om, hvordan Grundtvig opfattede tankegangen i udtrykket «Fuldkommenheds Baand».

Grundtvigs prædikener i 1847, 1848 og 1849 synes sammenlignet med hele perioden 1832-1856 at skille sig ud på mange forskellige måder. Et eksempel herpå er også, at begrebet «Faderligheden» forekommer langt oftere og med større vægt i disse tre år og specielt i 1848 end sædvanligt i 
Grundtvigs prædikener. ${ }^{24}$ Denne statistik synes at kunne underbygge, at Grundtvig med sin tale om «Fuldkommenheds Baand» også peger på en ideal tilstand nemlig en tilstand, som han både med hensyn til menigheden og med hensyn til det verdslige danske samfund modstiller til den moderne liberalistiske og individualistiske samfundsfilosofi altså de samfundstanker, som sejrede i Danmark i 1848.

\section{KONKLUSION: HVORFOR BENEGTER VERDEN, AT DEN SANDE KÆRLIGHED SKAL FINDES I FULDKOMMENHEDENS BÅND?}

De tanker, som bliver udfoldet i Grundtvigs tekster omkring udtrykket «Fuldkommenheds Baand», er på mange måder de modsatte af de tanker om værdien af det individuelle og særegne, som kom til at præge det 19. århundrede. Grundtvig talte bibelsk og paulinsk om at afdø og give afkald og om selvets og individets $\mathrm{d} \varnothing \mathrm{d}$, og om, at det kristne menneske ikke længere lever sit eget gamle liv, men nu lever inden i Kristus. Et sandt kristent menneske drives ikke længere af sine egne tanker eller følelser, og det gør ikke sine egne gerninger. ${ }^{25}$

Grundtvigs tanke var, at hvis et menneske ikke opdrages og formes af et faderligt samfund med fælles værdier, er det pågældende menneske fortabt i sin egen afmægtighed, individuelle vilje og blindhed og dermed udleveret til sine egne naturlige impulser. Grundtvigs tanke var, at hvis mennesker forbliver begrænsede af deres egen private, personlige, særegne individualitet, er de stadig lukket inde i syndens verden.

I sine tekster hævdede Grundtvig, at denne verden benægter, at den sande kærlighed skal findes i fuldkommenhedens bånd. At Grundtvig opfattede verdens falske opfattelse af kærligheden på denne måde er helt blevet forbigået i Grundtvig-forskningen, som tværtom har tillagt Grundtvig en slags naturlig opfattelse af kærligheden, som ligner den opfattelse, som Grundtvig netop kritiserede og angreb hos verden.

Grundtvig hævdede, at Kristus har fortalt os sandheden om alle ting såvel de jordiske som de himmelske ting, og, at vi - når vi skal forholde os til samfundsmæssige, moralske, kulturelle eller politiske spørgsmål - skal se alle ting «i Herrens Lys». ${ }^{26}$ De opfattelser af værdien af det naturlige og individuelle eller særegne, som Grundtvig bekæmpede, har siden vundet en stadig større udbredelse. På den måde er Grundtvigs tanker om værdien af det faderlige og den faderlige opdragelse og om «Fuldkommenheds Baand» måske endnu mere interessante i dag, end da disse tanker blev fremsat i midten af det 19. århundrede. 


\section{$\begin{array}{lllll}\mathbf{N} & \mathrm{O} & \mathbf{T} & \mathbf{E} & \mathbf{R}\end{array}$}

1 GPV II, 161-162. GPV bruges som forkortelse for: Jette Holm et al. (ed.): Grundtvig. Prcedikener i Vartov, I-VIII, København: Forlaget Vartov 2003 og 2007.

2 Kaj Thaning: Menneske forst - Grundtvigs opgør med sig selv, København 1963, 665. K. E. Bugge: Grundtvigs skoleskrifter, II, København 1968, 12. Helge Grell: Skaberordet og billedordet. Studier over Grundtvigs teologi om ordet. København 1980, 88, 89, 107, 140, 141, 142. Synnøve Sakura Heggem: Kjarlighetens makt, maskerade og mosaikk. En lesning af N. F. S. Grundtvigs Sang-Verk til den Danske Kirke (1837). Oslo: Unipub 2005, 177-178.

3 Uffe Jonas: «Kvinde-Evangeliet: Om Grundtvigs mandebilleder og kvindesyner», Grundtvig Studier, 2007, 174-175.

4 Grundtvig siger om de ømme følelser i en prædiken fra 1836: «Det er ikke med Ord og Tunge men med Gierning og Sandhed, der skal elskes; thi hvem agter det vel for Andet end Falskhed eller dog Fjas og Tant hvor ømt og kiærligt en Moder taler om og til sine Børn eller Egte-Fæller om og til hinanden» (GP IX, 243). GP bruges som en forkortelse for: Christian Thodberg (ed.): N. F. S. Grundtvigs prcedikener 1822-26 og 1832-39, I-XII, København: Gads Forlag 1983-1986.

5 GP XII, 229.

6 GP XII, 229.

7 GP XII, 106.

8 Salmen «Let er min Byrde» er udgivet i GSV V, 136-137, nr. 84. GSV er en forkortelse for: Grundtvigs Sang-Vark. I-VI. København: Det Danske Forlag 19441956.

9 Eksempler er: GP XII, 106, GP XII, 170, GP XII, 381, GP VII, 357, GP VIII, 169, GP XI, 86, og den utrykte prædiken «Skiærthorsdag 1848».

10 GP XII, 170.

11 GP VI, 131-136.

12 GP VI, 134.

13 GP VI, 135.

14 GP VI, 135-136.

15 Balslev 1955, 171. Balslev 1955 er her en forkortelse for: N. FS. Grundtvig. Christenhedens Syvstjerne. Udgivet med Oplysninger ved Th. Balslev. København: Kirkeligt Samfunds Forlag 1955.

16 GP II 109. I denne prædiken «Femte Søndag efter Helligtrekonger 1824. AftenSang» forklares udtrykket «Kiærlighed er Fuldkommenheds Baand» ikke færre end 33 forskellige steder! Denne prædiken er også et følelsesladet opgør med tidens voksende individualisme, selvklogskab og selvrådighed i den politiske og samfundsmæssige sfære.

17 Balslev 1955, 171.

18 Grundtvigs skoleverden $i$ tekster og udkast. Udgivet af Knud Eyvin Bugge. København: Institut for Dansk Kirkehistorie, G. E. C. Gad 1968, II, 12.

19 Holger Begtrup: Nik. Fred. Sev. Grundtvigs udvalgte Skrifter. VIII, København: Gyldendalske Boghandel, Nordisk Forlag 1909, 19. Sml. beskrivelserne af «Fuldkommenheds Baand» i samme udgave af «Gylden-Aaret» side 18, 20, 21, 22, 23, 24 og 25. - Også i Brage-Snak fra 1844 om den nordiske mytologi anvender Grundtvig tankegangen om «Fuldkommenheds Baand», som stammer fra hans beskrivelse af 
den kristne menighed, på almene ideale samfundsforhold og i en klar opposition til den liberale samfundsfilosofi: Jf. udgaven af Brage-Snak i anførte værk af Holger Begtrup VIII, 674-676. Også i Grundtvigs kirkehistorie Kirke-Speil fra 1871 fremhæves stærkt idealet om det faderlige samfund og «Fuldkommenheds Baand» (Jf. anførte udgave af Holger Begtrup X, 109, 206, 207).

20 Jf. de referencer til Grundtvig-forskningen, som blev anført ovenfor i note 2 og 3.

21 Ole Nyborg: «Grundtvig, dyden og kærligheden», Grundtvig Studier 2010, 96-126.

22 GSV I nr.23: "Christus den Første regierer endnu». Eksempler fra Grundtvigs prædikener er: GP II, 109-110, GP VIII, 243-244, GP XII, 338, GP XII, 229, GP X, 300, GP VI, 134-136, GP XII, 106, GPV II, 161-162 og den utrykte prædiken «Onsdag 1ste Aug. 1849».

23 Et nyligt eksempel er: Regner Birkelund: Frihed til falles bedste. En oppositionel stemme fra fortiden. Aarhus: Aarhus Universitetsforlag 2008.

24 Ole Nyborg: «Faderligheden», «Kiærligheden» og «Samfundet». Grundtvigs prædikener i Vartov især i kirkeårene 1847-1848 og 1848-1849.». Grundtvig Centerets konference: Grundtvig som samfundsbygger. Den 24. og 25. januar 2011. [http://grundtvigcenteret.au.dk/fileadmin/www.grundtvigcenteret.au.dk/

nyheder_og_arrangementer/arrangementsarkiv/

Grundtvig_som_samfundsbygger/Ole_Nyborg.pdf] (set den 29. juli 2011).

25 Følgende centrale værker fra de sidste ti års Grundtvig-forskning vedrørende Grundtvigs teologi og livs- og menneskeopfattelse nævner ikke med et eneste ord (!), at Grundtvig havde en tanke om martyriet: Birkelund 2008, Anja Stokholm: «Om forholdet mellem skabelse og syndefald hos Grundtvig og Luther», Grundtvig Studier 2003, 88-125, Kim Arne Pedersen: «'Sjæle og kroppe i tusindtal...' om samenhængen mellem menneskesyn og kirkesyn hos Grundtvig, undersøgt med baggrund i Kierkegaaards forfatterskab», i: Grundtvig - Kierkegaard. En samtale på høje tid, red. af Henrik Wigh-Poulsen, København: Vartov, 59-90, Betina Hjorth Præstegaard: «N. F. S. Grundtvigs syn på forholdet mellem skabelse, åbenbaring og nærværelse belyst ved en sammenligning med Jürgen Moltmann», Grundtvig Studier 2002, 81-120 og Hans Raun Iversen: Grundtvig, folkekirke og mission. Praktisk teologiske vekselvirkninger, København: Anis 2008.

26 Ole Nyborg: «Grundtvig, kristendom og politik», Dansk Tidsskrift for Teologi og kirke, nr. 2, 2011. 55-66. 


\section{DEN ØKONOMISKE KIRKEFRONT}

\section{Hvordan fikk prestene lønn under krigen?}

\section{BJØRN SANDVIK}

Prof. Dahls gt .21B

0353 Oslo

bj.sandvik@c2i.net

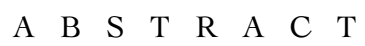

From the very beginning of the German occupation of Norway a severe conflict arose between the church and the Nazi authorities. In April 1942 it came to a dramatic climax, as the church broke its relations with the state, on the basis of the confession document «Kirkens grunn», «The foundation of the church», which was read from the pulpit in all churches on the first day of Easter. The pastors declared then that they would no longer serve as state officials, and consequently would no longer take salary from the state. From one week to another they had no income and living for themselves and their families. The congregations, however, felt a responsibility toward their ministers, and after a surprisingly short time a financial organization was constructed, with support from the congregations all over the country. The leader of this economic church front was the Oslo director Sam Knutzen. The work had to be done secretly, because the Nazi regime declared it to be illegal and hostile against the state.

This part of the church resistance movement in Norway has surprisingly enough not been examined by church historians. This article describes how the work was organized and kept secret, and those who were responsible throughout the country. For a period of three years the Norwegian church was in some respects a free church, totally independent of the state. In 1945 the state system continued as it had been before the war, but the recognition of the church as a religious fellowship, and not 